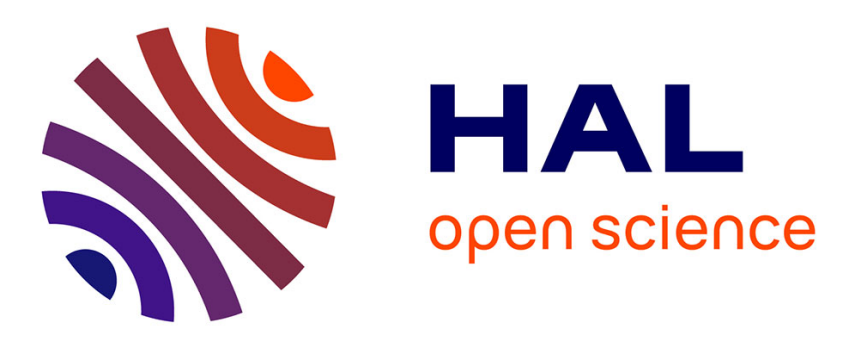

\title{
Spatial variations of dimethylsulfide and dimethylsulfoniopropionate in the surface microlayer and in the subsurface waters of the South China Sea during springtime
}

Gui-Peng Yang, Wei-Wen Jing, Zhi-Qiang Kang, Hong-Hai Zhang, Gui-Sheng Song

\section{To cite this version:}

Gui-Peng Yang, Wei-Wen Jing, Zhi-Qiang Kang, Hong-Hai Zhang, Gui-Sheng Song. Spatial variations of dimethylsulfide and dimethylsulfoniopropionate in the surface microlayer and in the subsurface waters of the South China Sea during springtime. Marine Environmental Research, 2007, 65 (1), pp.85. 10.1016/j.marenvres.2007.09.002 . hal-00562991

\section{HAL Id: hal-00562991 https://hal.science/hal-00562991}

Submitted on 4 Feb 2011

HAL is a multi-disciplinary open access archive for the deposit and dissemination of scientific research documents, whether they are published or not. The documents may come from teaching and research institutions in France or abroad, or from public or private research centers.
L'archive ouverte pluridisciplinaire HAL, est destinée au dépôt et à la diffusion de documents scientifiques de niveau recherche, publiés ou non, émanant des établissements d'enseignement et de recherche français ou étrangers, des laboratoires publics ou privés. 


\section{Accepted Manuscript}

Spatial variations of dimethylsulfide and dimethylsulfoniopropionate in the surface microlayer and in the subsurface waters of the South China Sea during springtime

Gui-Peng Yang, Wei-Wen Jing, Zhi-Qiang Kang, Hong-Hai Zhang, Gui-Sheng Song

PII:

S0141-1136(07)00113-4

DOI: 10.1016/j.marenvres.2007.09.002

Reference: MERE 3142

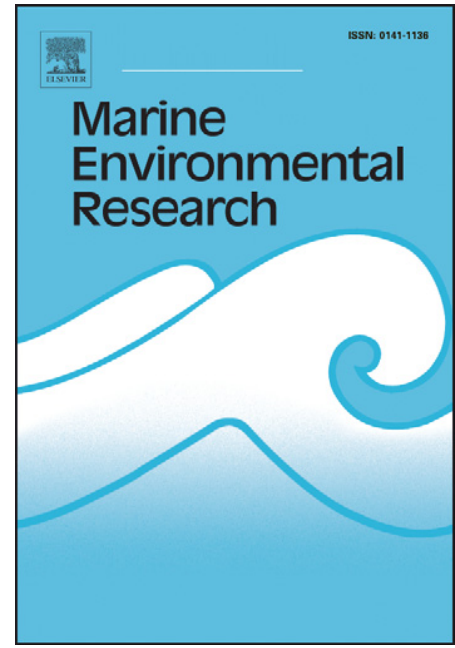

To appear in:

Marine Environmental Research

Received Date:

6 November 2006

Revised Date:

11 September 2007

Accepted Date:

13 September 2007

Please cite this article as: Yang, G-P., Jing, W-W., Kang, Z-Q., Zhang, H-H., Song, G-S., Spatial variations of dimethylsulfide and dimethylsulfoniopropionate in the surface microlayer and in the subsurface waters of the South China Sea during springtime, Marine Environmental Research (2007), doi: 10.1016/j.marenvres.2007.09.002

This is a PDF file of an unedited manuscript that has been accepted for publication. As a service to our customers we are providing this early version of the manuscript. The manuscript will undergo copyediting, typesetting, and review of the resulting proof before it is published in its final form. Please note that during the production process errors may be discovered which could affect the content, and all legal disclaimers that apply to the journal pertain. 
1 Spatial variations of dimethylsulfide and dimethylsulfoniopropionate in the surface

2 microlayer and in the subsurface waters of the South China Sea during springtime

\section{6}

7

$8 *$ To whom all correspondence should be addressed.

$9 \quad$ Prof. Gui-Peng Yang

10 College of Chemistry and Chemical Engineering

11 Ocean University of China

12 Qingdao 266100

13 China

14 E-mail: gpyang@mail.ouc.edu.cn

15 Tel: +86-532-66782657, 66781733

16 Fax: $+86-532-66782540$

17 


\title{
Spatial variations of dimethylsulfide and dimethylsulfoniopropionate in the surface
} microlayer and in the subsurface waters of the South China Sea during springtime

\author{
Gui-Peng Yang*, Wei-Wen Jing, Zhi-Qiang Kang, Hong-Hai Zhang, Gui-Sheng Song
}

Key Laboratory of Marine Chemistry Theory and Technology, Ministry of Education,

College of Chemistry and Chemical Engineering, Ocean University of China, Qingdao 266003, China

Abstract Spatial variations in dimethylsulfide (DMS) and dimethylsulfoniopropionate (DMSP) were surveyed in the surface microlayer and in the subsurface waters of the low productivity South China Sea in May 2005. Overall, average subsurface water concentrations of DMS and DMSP of dissolved (DMSPd) and particulate (DMSPp) fractions were 1.74 (1.00-2.50), 3.92 (2.21-6.54) and $6.06(3.40-8.68) \mathrm{nM}$, respectively. No enrichment in DMS and DMSPp was observed in the microlayer. In contrast, the microlayer showed a DMSPd enrichment, with an average enrichment factor (EF, defined as the ratio of the microlayer concentration to subsurface water concentration) of 1.40 . In the study area, none of the sulfur components were correlated with chlorophyll $a$. An important finding in this study was that DMS, DMSP and chlorophyll $a$ concentrations in the surface microlayer were respectively correlated with those in the subsurface water, suggesting a close linkage between these two water bodies. The ratios of DMS:Chl-a and DMSPp:Chl-a showed a gradually increasing trend from

North to South. This might be due to changes in the proportion of DMSP producers in the phytoplankton community with the increased surface seawater temperature. A clear diurnal variation in the DMS and DMSP concentrations was observed at an anchor station with the highest concentrations appearing during the day and the lowest concentrations during the night. The higher DMS and DMSP concentrations during daytime might be attributed to the light-induced increase in both algal synthesis and exudation of DMSP and biological production of DMS. The mean flux of DMS from the investigated area to the atmosphere was estimated to be $2.06 \mu \mathrm{mol} \mathrm{m} \mathrm{m}^{-1}$. This low DMS emission flux, together with the low DMS surface concentrations was attributed to the low productivity in this sea.

\footnotetext{
* Corresponding author. E-mail: gpyang@mail.ouc.edu.cn
} 


\section{Introduction}

5

Dimethylsulfide (DMS) produced by marine microbiota is by far the most abundant volatile sulphur

compound found in surface water, occurring at supersaturated concentrations and, hence, giving rise to the major part of the sulfur flux from the oceans to the atmosphere. DMS is oxidized to products such as submicron-size sulphate and sulphonate particles, which contribute to atmospheric acidity and aerosols, the latter leading to cloud condensation nuclei $(\mathrm{CCN})$, which have important consequences for the earth's radiation balance (Lovelock et al., 1972; Wakeham et al., 1984; Andreae, 1990). As a result, DMS is generally known to have a potential role in the global climate and in environmental changes.

The understanding of factors that regulate the near-surface concentrations of DMS in time and space is a

significant and specific problem that hampers more accurate knowledge of the sea-to-air flux (Andreae,

1990). Seasonal studies of oceanic DMS concentrations have shown that average surface seawater DMS

concentrations can vary by as much as a factor of 50 between summer and winter, ranging from

approximatively $0.2 \mathrm{nM}$ in winter to $10 \mathrm{nM}$ in summer (Leck et al., 1990; Nguyen et al., 1990; Berresheim et al., 1991; Shenoy and Patil, 2003). This large variability necessarily introduces an uncertainty regarding the global estimates of the emission fluxes to the atmosphere. As a result, DMS data must be available from as many sites as possible for any estimate of the flux to be reliable.

DMSP, which is the main precursor of DMS, is considered to be the key link between algal cells and atmospheric DMS. DMSP acts as an osmolyte and compatible solution produced by certain groups of macro- 
1 and micro-algae, having the similar structure as betaines. DMSP may constitute as much as $10 \%$ to $20 \%$ and

$250 \%$ to $90 \%$ of cellular organic carbon and sulfur, respectively (Bates et al., 1994; Matrai and Keller, 1994;

3 Matrai and Vernet, 1997). DMSP concentrations in seawater are usually much greater than DMS

4 concentrations, which are generally lower than $10 \mathrm{nM}$, except in coastal waters. DMSP is found in particulate

5 and dissolved fractions, referred to as DMSPp and DMSPd, respectively. Fractionation of the DMSP pool

6 with particulate and dissolved phases shows that both can behave completely differently in the water column.

7 DMSPd is believed to be more dynamic than DMSPp, with turnover times estimated to be on the order of hours in subtropical waters (Kiene et al., 2000). DMSPd has been suggested as the source of most DMS, with

9 partial conversion into DMS and partial metabolism to other products. Biosynthesis of intracellular DMSP is strongly species-dependent. It is generally thought that diatoms produce little DMSP while Dinophyceae and Prymnesiophyceae are important DMSP producers (Turner et al., 1988; Keller et al., 1989; Jean et al., 2005).

DMSP is released into seawater via a combination of processes involving the lysis of senescent cells, microand macro-zooplankton grazing, viral infections and then, converted into DMS by enzymatic cleavage

(Dacey and Wakeham, 1986; Nguyen et al., 1988). Because of its biogeochemical, ecological and biochemical implications, interest in DMSP is currently increasing and diversifying (Belviso et al., 1990; Yang et al., 2005a; Shenoy et al., 2006; Jean et al., 2006).

The sea surface microlayer has often been operationally defined as roughly the top several tens-several hundreds micrometres of the water surface, depending on the sampling method used (Liss and Duce, 1997).

The microlayer has physical, chemical and biological properties that are measurably different from those of adjacent subsurface waters (Liss and Duce, 1997). Over the past two decades, although there has been a great advance in understanding the biogeochemical cycling of biogenic sulfur in the bulk seawater, there remain many unknowns in understanding the distribution of biogenic sulfur in the microlayer (Yang et al., 2006). 
The South China Sea is the largest marginal sea next to the western boundary of the tropical Pacific. It

2 covers an area of $3.5 \times 10^{6} \mathrm{~km}^{2}$ and is characterized by high sea-surface temperatures and low productivity.

3 Oligotrophy and low productivity of the South China Sea have caused great interest in the study of

4 biogeochemistry of biogenic elements in this sea (Yang et al., 1999). Nevertheless, in comparison with other

5 China Seas distribution and emission of other sulfur compounds have received little attention. Considering

6 the potential importance of DMS and thus DMSP in the global climate, an in situ investigation in the South

7 China Sea was carried out to better understand the distribution of DMS and DMSP between the surface microlayer and the subsurface waters and its controlling factors. More generally this study produced a better

9 knowledge of the DMS emission flux to atmosphere. Moreover, the enrichment factor (EF) of DMS(P) was

calculated to evaluate their extent of enrichment in the microlayer relative to subsurface waters. This factor could be applied in studies carried out in other oceans and be of great importance to estimate the DMS contribution to the global climate. The present study represents the first comprehensive description of the distribution of DMS, DMSP and chlorophyll $a$ in the surface microlayer of the South China Sea.

\subsection{Sample collection}

May 2005 is shown in Fig. 1. This work was undertaken as part of the Chinese Surface Ocean-Lower

Atmosphere Study (SOLAS). This cruise included 22 grid stations and one 24-hour anchor station. The 
1 temperature and salinity are described in Table 1. The sampling stations, centered by S10, were set up

2 according to $1^{\circ} \times 1^{\circ}$ resolution in the rectangular region from $115^{\circ} \mathrm{E}, 16^{\circ} \mathrm{N}-118^{\circ} \mathrm{E}, 20^{\circ} \mathrm{N}$. Additionally, seven

3 stations (S17 S23) were scattered on a section of the continental shelf-continental slope-deep-sea basin.

4 Over 20 different sampling techniques have been applied to sample the sea surface microlayer (Hardy,

5 1982; Liss and Duce, 1997). Among these, the metal screen and the glass plate are the most commonly used

6 samplers for microbiological and chemical investigations of the microlayer. Our field investigation showed

7 that the screen sampler was superior to the glass plate in efficiency in collecting the microlayer DMS (Yang

8 et al., 2001). In the present study, the sea-surface microlayer samples were collected from the ship's stern

9 using the screen sampler which was made of a 16-mesh stainless steel screen incorporated into a $40 \times 40 \mathrm{~cm}^{2}$

stainless steel frame (Garret, 1965). In practice, the screen was placed through the water surface. It was then

withdrawn horizontally (parallel to water) through the water surface and drained immediately into a sample

bottle. Almost all (>95\%) the seawater and sulfur species entrapped by the mesh spaces were retrieved from

the screen sampler. This procedure was repeated until the sample bottle was filled. Approximately 20 surface

contacts were required to collect a 0.6 -liter sample. The sampling of the microlayer was generally achieved in

$20 \mathrm{~min}$. The physical thickness of the screen-collected microlayer sample was typically $200 \pm 10 \mu \mathrm{m}$. The

subsurface water samples were simultaneously collected from a depth of $20 \mathrm{~cm}$ using a 1-liter brown glass

bottle. The bottle was opened and closed in place to avoid surface microlayer interference. The surface

Canada). 
1 Once collected, the DMS samples were immediately analyzed on board using a purge-and-trap

2 pre-concentration technique (Yang and Tsunogai, 2005). Briefly, the samples (typically 15 ml) were sparged

3 with high purity nitrogen at $40-50 \mathrm{ml} / \mathrm{min}$ for $15 \mathrm{~min}$. The evolved gas was dried and then trapped in a

4 U-shaped tube packed with Tenax-TA at dry ice-ethanol temperature $\left(-78^{\circ} \mathrm{C}\right)$. The trapped gases were then

5 desorbed with hot water $\left(\sim 90^{\circ} \mathrm{C}\right)$ and analyzed using a Shimadzu-14B gas chromatograph equipped with a

6 flame photometric detector. The chromatographic column used was a $2 \mathrm{~m} \times 3 \mathrm{~mm}$ glass column packed with

7 DEGS on Chromosorb W-AW-DMCS. Calibration was regularly performed by injecting known amounts of

DMS in an ethylene glycol solution into the bubbling chamber and treating them with the same procedure as the samples. Replicate analyses were conducted for all the DMS samples. The analytical precision was generally better than $5 \%$. The detection limit for DMS was $0.1 \mathrm{nM}$.

DMSP was analyzed by alkaline cleavage to DMS with a 1:1 ratio (Dacey and Blough, 1987). For the determination of DMSPd, the sample was filtered through a Whatman GF/F filter $(0.7 \mu \mathrm{m}$ nominal retention $)$.

The filtrate was placed into a $40 \mathrm{ml}$ glass vial containing $2 \mathrm{ml}$ of $10 \mathrm{M} \mathrm{NaOH}$ solution (with a final $\mathrm{pH} \sim 13.5$ ). The vial was immediately sealed, leaving no headspace. For the DMSPp determination, the filter was quickly placed into a $40 \mathrm{ml}$ vial containing $2 \mathrm{ml}$ of $10 \mathrm{M} \mathrm{NaOH}$, which was immediately filled with distilled water and sealed. The samples were left to react in the dark at room temperature for at least $24 \mathrm{~h}$ in order to completely convert DMSP to DMS. The liberated DMS was measured using the method described above. The precision of replicate DMSP determinations was generally better than $10 \%$. The detection limit for DMSP was $0.1 \mathrm{nM}$.

Chlorophyll $a$ was measured fluorometrically with a Turner Design Fluorometer after filtration of 1000 $\mathrm{ml}$ of seawater on Whatman GF/F filter and extraction with $90 \%$ acetone (Parsons et al., 1984). 


\section{3. Results and discussion}

2

Since the South China Sea is situated in the tropical zone, its sea-surface temperature is consistently high, not dropping below $22^{\circ} \mathrm{C}$ throughout the year. The photic zone depth is also persistently deep and exceeds the mixed-layer depth and the top of the nutricline in most of the year (Tseng et al., 2005). Thus, the primary production in the South China Sea is not limited by the availability of light, but the availability of the nutrients. A multitude of rivers bring an abundance of terrestrial material into the South China Sea and contribute to high sedimentation rates, at several $\mathrm{cm}$ kyear ${ }^{-1}$, especially from April to September (Lee et al., 1999). However, the basin-wide surface circulation gyres effectively isolate the interior of the South China Sea proper from the influence of land-runoff. As a result, the deep central South China Sea is still oligotrophic, like the interior of the major ocean basins. Besides, the South China Sea is situated between the western Pacific warm pool and the Tibetan Plateau, which is under the persistent influence of monsoonal winds: a strong northeast monsoon between November and April and a weaker southwest monsoon between June and September. Between these two monsoonal seasons, in May and October, the wind is weak and variable (Liu et al., 2002). These monsoonal winds play a major role in the oceanography of the South China Sea.

\subsection{DMS, DMSP and chlorophyll a concentrations in the subsurface water}

Table 1 presents SST, salinity and water depth in the study area. Throughout the study area, surface water salinity varied little while SST strongly varied from $30.41^{\circ} \mathrm{C}$ to $24.83^{\circ} \mathrm{C}$. In the South China Sea, owing to the pycnocline, deeper nutrient-rich water does not reach the surface (Yang et al., 1999). Nutrient 
1 limitation in surface water, together with high solar radiation, makes the South China Sea a low-productivity

2 region (Han, 1998). Therefore, very low concentrations of chlorophyll $a$ with a mean of $0.08 \mu \mathrm{g} \mathrm{L} \mathrm{L}^{-1}$ were

3 found in the study area. However, DMS concentrations were obviously higher than those expected based on

4 the phytoplankton biomass in this region. The highest DMS concentration of $2.50 \mathrm{nM}$ was observed at shelf

5 station S23 where elevated inputs of continental-derived nutrients and organic matter occurred. Overall DMS

6 concentrations in the subsurface water averaged to $1.74 \mathrm{nM}$. In oligotrophic waters, DMSP production was

7 mostly associated with small algae that contributed little chlorophyll $a$ but were better adapted to high light and nutrient deficiency (Kiene et al., 2000). The field investigation has shown that the oligotrophic South

9 China Sea contains abundant dinoflagellates which account for $43 \%$ of the total phytoplankton species, far exceeding other areas in China Seas (Han, 1998). This class of alga may be a major source of the relatively high DMS levels in this chlorophyll-poor sea.

concentrations found in the open sea. This was in good agreement with the previous studies which showed that the concentrations of DMS in the oceans generally exhibited a latitudinal variation with higher values at al., 1991). value was measured at the open sea station S16. The mean concentration of DMSPd was $3.92 \mathrm{nM}$, dominating over that of DMS. In comparison, the concentrations of DMSPp showed greater variations than those of DMSPd and DMS, with the maximum value $(8.68 \mathrm{nM})$ appearing at station $\mathrm{S} 22$ and the minimum 
1 DMSPd and DMSPp did not display the same distribution pattern as chlorophyll $a$ or DMS. For example,

2 continental shelf station S22 and pelagic station S17 revealed a similar chlorophyll $a$ level, but DMSPd and

3 DMSPp concentrations at station S22 were evidently higher than at station S17. Chlorophyll $a$ concentrations

4 were basically equal at two adjacent stations, S1 and S8, whereas DMSPd and DMSPp concentrations at the

5 two sites differed largely. As a consequence, no correlation appeared between these parameters.

6

\subsection{DMS, DMSP and chlorophyll a concentrations in the microlayer and their enrichment factors}

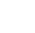

(1)

The distribution of DMS in the microlayer revealed a consistent pattern with that in the subsurface water, with the maximum concentration existing at station S23 and the minimum value occurring at station S21. A statistically significant relationship $\left(r^{2}=0.4003, n=22, p=0.0016\right)$ was found between the microlayer and subsurface water concentrations of DMS, suggesting that variation in the microlayer DMS concentration followed roughly the variation with its subsurface water concentration. In comparison with the subsurface water, the surface microlayer exhibited a greater spatial variability in the DMSPd concentrations with a range of 2.70-8.95 nM (mean: $5.18 \mathrm{nM}$ ). Like the case of DMS, the microlayer DMSPd concentrations were also correlated to its subsurface water concentrations $\left(r^{2}=0.4048, n=22, p=0.0015\right)$. Similarly, the microlayer DMSPp and chlorophyll $a$ concentrations were also respectively correlated with their subsurface water concentrations (for DMSPp, $r^{2}=0.4373, n=22, p=0.0008$; for chlorophyll $\left.a, r^{2}=0.5147, n=20, p=0.0004\right)($ Fig. 2). The above observations suggested that material in the microlayer was directly dependent upon the diffusive supply from the bulk liquid below. Throughout the study period, our sampling of the surface microlayer proceeded on a calm sea surface at a relatively low wind speed, which indicated that vertical mixing of microlayer water with bulk water might play a minor part in determining the distribution of DMS 
1 and DMSP between these two water compartments in the study area. So other transport processes such as

2 molecular diffusion and thermodiffusion may act as the major controlling factors for the exchange of

3 substance between the microlayer and bulk water. In addition to the above physical processes, some

4 biological factors such as the planktonic migration might also play a role.

5 The microlayer is a region where physical, chemical and biological properties are most altered relative

6 to subsurface water. Many previous studies have demonstrated that the surface microlayer is characterized by

7 enhanced levels of various particulate and dissolved organic substances (Hardy, 1982). The enrichment factor

8 EF is defined as the ratio of the microlayer concentration $\left(C_{\mathrm{M}}\right)$ to subsurface water concentration $\left(C_{\mathrm{S}}\right)$, which

9 was used to indicate the extent of enrichment of material in the microlayer relative to subsurface water (Liss

and Duce, 1997). As shown in Table 2, the EFs of DMS ranged between 0.53 and 1.19, with only two stations

showing EF value larger than unity, indicating that no microlayer enrichment occurred for DMS. Recently, it

was demonstrated that photochemical process might be important in the removal of DMS in the photic zone

(Brugger et al., 1998). The microlayer is exposed to more intense solar radiation relative to the subsurface

water and may enhance DMS photochemical loss. This is a probable reason why the DMS concentrations and thus derived EF values were lower in the microlayer.

indicating that DMSPd was accumulated to a small extent in the microlayer. This could be attributed to the

Gibbs surface adsorption process (Adamson, 1976), since high surface tension of the air-water interface

energetically favors adsorption of dissolved organic substances such as DMSPd. However, compared with

Sea was smaller, namely the continental shelf water samples showed a greater enrichment degree than the 
1 had been discussed by Yang and Tsunogai (2005). Besides physical factors, biological activity may also affect

2 the enrichment of material in the microlayer (Yang et al., 2001; Yang and Tsunogai, 2005). In a previous

3 investigation for Funga Bay, Japan, we found that high concentrations of DMSP in the microlayer generally

4 appeared in the samples which contained high levels of chlorophyll a, suggesting that in situ production from

5 phytoplankton may be an extremely important source for the microlayer DMSP (Yang et al., 2005b). In a

6 recent survey for the western North Atlantic, we further found that great microlayer enrichments of DMSPd

7 were observed mostly during the phytoplankton bloom when chlorophyll $a$ appeared to have accumulated in the microlayer (Yang et al., 2005a). This may be attributed to the enhanced production of DMSPd in the

9 microlayer, due to higher phytoplankton biomass here. The above observation suggested that chlorophyll $a$

enrichment extent in the microlayer might be an important factor affecting the extent of enrichment of DMSP

in the microlayer. Therefore, the smaller enrichment degree of DMSPd in the surface microlayer of the South

China Sea may be partially attributed to very low chlorophyll $a$.

In comparison to DMSPd, DMSPp did not show significant enrichment in the microlayer with reference

to the underlying water. The microlayer surface tension is generally an important factor for controlling the extent of enrichment of particulate species. It is known that phytoplankton can produce large amounts of surface-active materials (Frew et al., 1990). These surface-active materials readily adsorb from seawater onto the surface of suspended particles, which is likely to make them adhere to the air-water interface. However, phytoplankton biomass in the study area was considerably low, as indicated by the chlorophyll $a$ levels (Table

2). The low phytoplankton biomass, together with inadequacy of nutrients in the surface seawater (according lead to "clean seawater" and hence low surface tension in the microlayer. This force seemed not to be enough 
1 was expected in the study area. Besides, gravitational precipitation process of particles from the microlayer to

2 bulk water may also contribute to little difference in the DMSPp concentrations between the microlayer and

3 subsurface water and thus low extent of enrichment of DMSPp in the microlayer.

5 3.3. Ratios of DMS:Chl-a and DMSPp:Chl-a in the subsurface water and surface microlayer

6

The ratios of DMS:Chl-a and DMSP:Chl-a can be used to compare the distribution of the biogenic sulfur in different trophic regions (Belviso et al., 2000). In the subsurface water, the highest DMS:Chl-a ratio was found at station $\mathrm{S} 2$ where chlorophyll $a$ concentration was the minimum, while the lowest ratio was observed at station S19 with relatively low DMS concentration. In comparison, the DMS:Chl-a values in the microlayer were slightly lower than those in the subsurface water, due to lower DMS concentrations here. The total average of DMS:Chl-a in the microlayer and subsurface water was 17.80 and $22.90 \mathrm{mmol} \mathrm{g}^{-1}$, respectively. The similar distribution pattern was also observed for the DMSPp:Chl-a, with average ratios of $83.80 \mathrm{mmol} \mathrm{g}^{-1}$ in the microlayer and $77.90 \mathrm{mmol} \mathrm{g}^{-1}$ in the subsurface water, respectively. Both DMS:Chl-a and DMSPp:Chl-a ratios obtained in this study were typical of oligotrophic ocean waters, in good agreement with previous studies (Iverson et al.,1989; Besiktepe et al., 2004).

In the present study, sampling stations were divided into five transects: T1 (S17-S23), T2 (S13-S16), T3 (S9, S11, S12), T4 (S5-S8) and T5 (S1-S4). The DMS:Chl-a and DMSPp:Chl-a ratios at all stations and their averages in each transect were plotted in Fig. 3. From Fig. 3 it is apparent that the average ratio of DMS:Chl-a in each transect showed a gradually increasing trend from north to south (i.e. from T1 to T5) in the microlayer as well as in the subsurface water. The spatial changes in DMSPp:Chl-a ratios also exhibited a similar trend, indicating an increase in the proportion of DMSP producers in the total phytoplankton 
1 assemblage. According to the previous study by Zhu et al. (2003), the phytoplankton community in the

2 summer South China Sea was dominated mainly by diatoms, dinoflagellates and cyanobacteria. Along with

3 the increase of SST from North to South, the dominant phytoplankton species changed gradually from

4 eurytopic group (e.g., diatoms) to warm water group such as dinoflagellates and cyanobacteria which are

5 generally considered to be prolific producers of DMSP. This may clearly explain why DMSPp:Chl-a ratios

6 increased gradually from T1 to T5.

7

8

9

\subsection{Diurnal variations in DMS and DMSP}

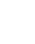

O

The diurnal changes in DMS and DMSP concentrations in the surface microlayer and subsurface water were investigated at an anchor station S10, as shown in Fig. 4. It is clear from Fig. 4 that DMS concentrations were the highest at 09:00 and the lowest at 00:00 in the subsurface water. DMS concentration in the microlayer exhibited a similar change trend to that in the subsurface water. The increase in DMS concentration in the morning might be attributed to a physiological response of algae to the increase in sunlight irradiance or the photoinhibition of bacterial DMS consumption. From 09:00 to 15:00, the DMS concentrations gradually decreased, probably due to enhanced photo-oxidation loss. The DMS concentration remained relatively constant throughout the night but obviously lower than that in the daytime. The lower DMS concentration in the night might be associated with its low biological production rate or high bacterial consumption rate at the same time.

In comparison, DMSP showed a different variation pattern from DMS. DMSPd and DMSPp concentrations in the subsurface water exhibited larger variations than DMS, with high value at noon and low values in the night. The diel variation of DMSPd and DMSPp in the microlayer showed a similar pattern to 
1 that in the subsurface water, with high values appearing in the afternoon and low values occurring during the

2 night. Our observation may be supported by some previous researches which showed that DMSP production

3 in unicellular algae was a diurnal process proportional to photosynthesis (Kuipers et al., 2000; Simó et al.,

4 2002; Merzouk et al., 2004). For instance, Simó et al. (2002) showed a light-induced increase in algal

5 synthesis and exudation of DMSP which exhibited a diel pattern peaking around noon. Kuipers et al. (2000)

6 found that solar UV radiation could inhibit bacterial activity and growth, causing an accumulation of DMSP

7 during daytime.

8

9 3.5. Sea-to-air fluxes of DMS in the study area

Using the surface microlayer DMS concentrations presented here, we have made an estimate of the emission flux of DMS from the South China Sea to the atmosphere according to the equation of Liss and Merlivat (1986):

where $K$ is the transfer velocity of DMS in the water phase, and $\Delta C$ is the concentration difference of DMS in

seawater and the atmosphere, assumed to be equal to the aqueous concentration, $C w$, since atmospheric

concentration of DMS was very low. The transfer velocity $K$ was calculated as a function of the wind speed

and the Schmidt number (Sc) (Liss and Merlivat, 1986). The Sc of DMS at the local temperature was derived

from the equation put forward by Saltzman et al. (1993). The $F_{D M S}$ values estimated according to the above approaches were presented in Table 3.

In the present study, the DMS fluxes ranged from 0.01 to $5.77 \mu \mathrm{mol} \mathrm{m} \mathrm{m}^{-1}$ with an average of 2.06 
1 the South China Sea in winter (Yang et al., 1999), which was primarily due to the great difference in the wind

2 speeds during the sampling periods. Also, it is reasonably lower than the DMS flux value of $3.4 \mu \mathrm{mol} \mathrm{m} \mathrm{m}^{-1}$

3 estimated by Yang et al. (2000) in the East China Sea which exhibited obviously higher primary productivity

4 and DMS levels than the tropical South China Sea. However, our results were consistent with that reported by

5 Simó et al. (1997) in the western Mediterranean waters, which was of $2.7 \mu \mathrm{mol} \mathrm{m}^{-2} \mathrm{~d}^{-1}$.

6

7

8

9

\section{Conclusions}

(1)

(1)

The present study provides further information for understanding the distribution of DMS, DMSPd and

DMSPp in the sea-surface microlayer and subsurface water. In the study area, DMS displayed a general decrease in concentration with distance from the land, with the low concentrations found in the open sea. The data presented here demonstrated that variation in the DMS, DMSPd, DMSPp and chlorophyll a concentrations in the surface microlayer followed closely variation with those in the subsurface water. Thus, it is likely that the materials in the microlayer will be dependent upon the diffusive supply from the bulk liquid below. It is worth noting that increased DMS(P):Chl-a ratios from North to South corresponded to increased seawater temperatures resulting in changes in the phytoplankton community. Our study showed that the DMS, DMSPd and DMSPp concentrations exhibited a clear diurnal variation with the highest values observed during the daytime and the lowest valued found in the night. This pattern may indicate a

light-induced increase in algal synthesis and exudation of DMSP. Consequently, temporal variations in biogenic DMS output from the surface waters may be explained by the variation in solar radiation. Of the three sulfur components investigated in the study, only DMSPd appeared to be significantly enriched in the microlayer. However, the influence of environmental factors upon the distribution and enrichment of DMSPd 
1 in the microlayer has not been fully understood and is worthy of further study.

2

\section{Acknowledgements}

4

5

6

\section{References} $35,1810-1821$.

We are thankful to the officers and crew aboard the R/V "Dong Fang Hong No. 2" for help and cooperation during the in situ investigation. Multiple sources of funding are acknowledged: the Natural Science Foundation of China under grant Nos. 40476034, 40525017 and 40490265, and the Taishan Mountain Scholar Construction Engineering Special Fund of Shandong Province, China. We are also grateful to Dr. Natacha Jean and an anonymous reviewer for their valuable comments to improve the manuscript.

Adamson, A.W., 1976. Physical Chemistry of Surfaces. 3rd edn. Wiley, New York, 698 pp.

Andreae, M.O., 1990. Ocean-atmosphere interactions in the global biogeochemical sulfur cycle. Marine Chemistry 30, 1-29.

Bates, T.S., Kiene, R.P., Wolfe, G.V., Matrai, P.A., Chavez, F.P., Buck, K.R., Blomquist, B.W., Cuhel, R.L., 1994. The cycling of sulfur in surface seawater of the northeast Pacific. Journal of Geophysical Research 99, 7835-7843.

Belviso, S., Christaki, U., Vidussi, F., Marty, J.C., Vila, M., Delgado, M., 2000. Diel variations of the DMSP-to-chlorophyll $a$ ratio in northwestern Mediterranean surface waters. Journal of Marine Systems 25, 119-128.

Belviso, S., Kim, S.K., Rassoulzadegan, F., Krajka, B., Nguyen, B.C., Mihalopoulos, N., Buat-Menard, P., 1990. Production of dimethylsulfonium propionate (DMSP) and dimethylsulfide (DMS) by a microbial food web. Limnology and Oceanography

Berresheim, H., Andreae, M.O., Iverson R.L., LI, S.M., 1991. Seasonal variations of dimethylsulfide emissions and atmospheric sulfur and nitrogen species over the western north Atlantic Ocean. Tellus 43, 353-372. 
1 Besiktepe, S., Tang, K.W., Vila, M., Simó, R., 2004. Dimethylated sulfur compounds in seawater, seston and mesozooplankton

2

3

4

5

6

7

8

9 in the seas around Turkey. Deep-Sea Research I 51, 1179-1197.

Brugger, A., Slezak, D., Obernosterer, I., Herndl, G.J., 1998. Photolysis of dimethylsulfide in the northern Adriatic Sea: dependence on substrate concentration, irradiance and DOC concentration. Marine Chemistry 59, 321-331.

Cline, J.D., Bates, T.S., 1983. Dimethylsulfide in the equatorial Pacific Ocean: a natural source of sulfur to the atmosphere. Geophysical Research Letters 10, 949-952.

Dacey, J.W.H., Blough, N.V., 1987. Hydroxide decomposition of DMSP to form DMS. Geophysical Research Letters 14, 1246-1249.

Dacey, J.W.H., Wakeham, S.G., 1986. Oceanic dimethylsulfide: production during zooplankton grazing on phytoplankton. Science 233, 1313-1316.

Frew, N. M., Goldman, J. C., Dennett, M. R., Johnson, A. S., 1990. Impact of phytoplankton-generated surfactants on air-sea gas exchange. Journal of Geophysical Research 95C, 3337-3352.

Garrett, W. D., 1965. Collection of slick-forming materials from the sea surface. Limnology and Oceanography 10, 602-605.

Han, W.-Y. (eds.), 1998. Marine Chemistry in the South China Sea. Science Publishing Company, Beijing, 174 pp.

Hardy, J.T., 1982. The sea surface microlayer: biology, chemistry and anthropogenic enrichment. Progress in Oceanography 11,

$$
307-328 \text {. }
$$

Iverson, R.L., Neaehoof, F.L., Andreae, M.O., 1989. Production of dimethylsulfoniumpropionate and dimethylsulphide by phytoplankton in estuarine and coastal waters. Limnology and Oceanography 34, 53-67.

Jean, N., Bogé, G., Jamet, J. L., Richard, S., Jamet, D., 2005. Annual contribution of different plankton size classes to particulate dimethylsulfoniopropionate in a marine perturbed ecosystem. Journal of Marine Systems 53, 235-247.

Jean, N., Bogé, G., Jamet, J. L., Jamet, D., 2006. Comparison of $\beta$-dimethylsulfoniopropionate (DMSP) levels in two mediterranean ecosystems with different trophic levels. Marine Chemistry 101, 190-202. 
1 Keller, M.D., Bellows, W.K., Guillard, R.R.L., 1989. Dimethyl sulfide production in marine phytoplankton. P.167-182. In

2

3 Biogenic Sulfur in the Environment, ed. by E. S. Saltzman and W. J. Cooper, American Chemical Society, Washington, D.C.

Kiene, R.P., Linn, L.J., Bruton, J.A., 2000. New and important roles for DMSP in marine microbial communities. Journal of Sea Research 43, 209-224.

Kuipers, B., van Noort, G.J., Vosjan, J., Hernal, G., 2000. Diel periodicity of bacterioplankton in the euphotic zone of the subtropical Atlantic Ocean. Marine Ecology Progress Series 201, 13-25.

Leck, C., Larsson, U., Bagander, L.E., Johansson, S., Haidu, S., 1990. Dimethylsulfide in the Baltic Sea: Annual variability in relation to biological activity. Journal of Geophysical Research 95, 3353-3364.

Lee, M.-Y, Wei, K.-Y., Chen, Y.-G., 1999. High resolution oxygen isotope stratigraphy for the last 150,000 years in the southern South China Sea: Core MD972151. Terrestrial, Atmospheric and Oceanic Sciences 10, 239-254.

Liss, P.S., Duce, R. (Eds.), 1997. The Sea Surface and Global Change. Cambridge University Press, Cambridge, 289 pp.

Liss, P.S., Merlivat, L., 1986. Air-sea gas exchange rates: introduction and synthesis. P.113-127. In The Role of Air-Sea Exchange in Geochemical Cycling, ed. by P. Buat-Menard, Reidel, Dordrecht.

Liu, K.-K., Chao, S.-Y., Shaw, P.-T., Gong, G.-C., Chen, C.-C., Tang, T.-Y., 2002. Monsoon-forced chlorophyll distribution and primary production in the South China Sea: observations and a numerical study. Deep-Sea Research 49, 1387-1412.

Lovelock, J.E., Maggs, R.J., Rasmussen, R.A., 1972. Atmospheric dimethylsulfide and the natural sulphur cycle. Nature 237, 452.

Matrai, P.A., Keller, M.D., 1994. Total organic sulfur and dimethylsulfoniopropionate in marine phytoplankton: intracellular variations. Marine Biology 119, 61-68.

Matrai, P.A., Vernet, M., 1997. Dynamics of the vernal bloom in the marginal ice zone of the Barents Sea: dimethylsulfide and dimethylsulfoniopropionate budgets. Journal of Geophysical Research 102, 22965-22979. 
1 Merzouk, A., Levasseur, M., Scarratt, M., Michaud, S., Gosselin, M., 2004. Influence of dinoflagellate diurnal vertical

2 migrations on dimethylsulfoniopropionate and dimethylsulfide distribution and dynamics (St. Lawrence Estuary, Canada).

3 Canadian Journal of Fisheries and Aquatic Sciences 61, 712-720.

4 Nguyen, B.C., Belviso, S., Mihalopoulos, N., Gaston, J., Nival, P., 1988. Dimethylsulfide production during natural 5 phytoplankton blooms. Marine Chemistry 24, 133-141.

6 Nguyen, B. C., Mihalopoulos, N., Belviso, S., 1990. Seasonal variation of atmospheric dimethylsulfide at Amsterdam Island in

7 the southern Indian Ocean. Journal of Atmospheric Chemistry 11, 123-141.

Parsons, T.R., Maita, Y., Lalli, C.M., 1984. A Manual for Chemical and Biological Methods for Seawater Analysis. Pergamon Press, Oxford.

Saltzman, E.S., King, D.B., Holmen, K., Leck, C., 1993. Experimental determination of the diffusion coefficient of dimethylsulfide in water. Journal of Geophysical Research 98, 16481-16486.

Shenoy, D.M., Patil, J. S., 2003. Temporal variations in dimethylsulphoniopropionate and dimethyl sulphide in the Zuari estuary, Goa (India). Marine Environmental Research 56, 387 - 402.

Shenoy, D.M., Paul, J. T., Gauns, M., Ramaiah, N., Kumar, M. D., 2006. Spatial variations of DMS, DMSP and phytoplankton in the Bay of Bengal during the summer monsoon 2001. Marine Environmental Research 62, 83 - 97.

Simó, R., Archer, S.D., Pedrós-Alió, C., Gilpin, L., Stelfox-Widdicombe, C.E., 2002. Coupled dynamics of dimethylsulfoniopropionate and dimethylsulfide cycling and the microbial food web in surface waters of the North Atlantic. Limnology and Oceanography 47, 53-61.

Simó, R., Grimalt, J.O., Albaigles, J., 1997. Dissolved dimethylsulphide, dimethyl-sulphoniopropionate and dimethylsulfoxide in western Mediterranean waters. Deep-Sea Research II 44, 929-950.

Tseng, C.-M., Wong, G.T.F., Lin, I.-I., Wu, C.-R., Liu, K.-K., 2005. A unique seasonal pattern in phytoplankton biomass in low-latitude waters in the South China Sea. Geophysical Research Letters 32(8), 8608-8610. 
1 Turner, S.M., Malin, G., Liss, P.S., Harbour, D.S., Holligan, P.M., 1988. The seasonal variation of dimethyl sulfide and

2 dimethylsulfoniopropionate concentrations in nearshore waters. Limnology and Oceanography 33, 364-375.

3 Wakeham, S. G., Howes, B. L., Dacey, J. W. H., 1984. Dimethyl sulfide in a stratified coastal salt pond. Nature 310, 770-772.

4 Yang, G.-P., Jing, W.-W., Li, L., Kang, Z.-Q., Song, G.-S., 2006. Distribution of dimethylsulfide and dimethylsulfoniopropionate

5 in the surface microlayer and subsurface water of the Yellow Sea, China during spring. Journal of Marine Systems 62:

$622-34$

7 Yang, G.-P., Liu, X.-T., Li, L., Zhang, Z.-B., 1999. Biogeochemistry of dimethylsulfide in the South China Sea. Journal of Marine Research 57, 189-211.

Yang, G.-P., Levasseur, M., Michaud, S., Scarratt, M., 2005a. Biogeochemistry of dimethylsulfide (DMS) and dimethylsulfoniopropionate (DMSP) in the surface microlayer and subsurface water of the western North Atlantic during

Yang, G.-P., Tsunogai, S., 2005. Biogeochemistry of dimethylsulfide (DMS) and dimethylsulfoniopropionate (DMSP) in the surface microlayer of the western North Pacific. Deep-Sea Research I 52 (4), 553-567.

Yang, G.-P., Tsunogai, S., Watanabe, S., 2005b. Biogeochemistry of dimethylsulfoniopropionate (DMSP) in the surface microlayer and subsurface seawater of Funka Bay, Japan. Journal of Oceanography 61, 69-78.

Yang, G.-P., Zhang, J.-W., Li, L., Qi, J.-L., 2000. Dimethylsulfide in the surface water of the East China Sea. Continental Shelf Research 20, 69-82.

Zhu, G.-H., Ning, X.-R., Cai, Y.-M., Liu, Z.-L., Liu, Z.-G., 2003. Studies on species composition and abundance distribution of 
3

Table 1. Description of the sampling stations.

5 Table 2. Distribution of DMS, DMSPd, DMSPp and chlorophyll $a$ in the surface microlayer and in the subsurface waters of the South China Sea during May 2005.

7 Table 3 . The calculated $S c$ and $K_{D M S}$ values and sea-to-air fluxes of DMS in the South China Sea.

8

9

10

11

12

13

14

15

16

17

18

19

20

21

22 


\section{ACCEPTED MANUSCRIPT}

2 Table 1. Description of the sampling stations.

\begin{tabular}{|c|c|c|c|c|c|}
\hline Station & Latitude & Longitude & Salinity & $\operatorname{SST}\left({ }^{\circ} \mathrm{C}\right)$ & $\begin{array}{c}\text { Water Depth } \\
\quad(\mathrm{m})\end{array}$ \\
\hline S1 & 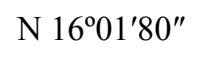 & E $115^{\circ} 06^{\prime} 99^{\prime \prime}$ & 34.126 & 28.75 & 4177 \\
\hline S2 & 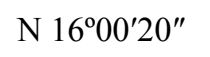 & E $116^{\circ} 00^{\prime} 05^{\prime \prime}$ & 34.025 & 29.43 & 4175 \\
\hline S3 & 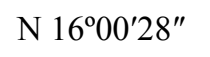 & E $117^{\circ} 00^{\prime} 60^{\prime \prime}$ & 34.143 & 30.41 & 4204 \\
\hline S4 & N 16o의 $16^{\prime \prime}$ & E $117^{\circ} 59^{\prime} 34^{\prime \prime}$ & 34.151 & 29.63 & 4830 \\
\hline S5 & N $17^{\circ} 00^{\prime} 55^{\prime \prime}$ & E $118^{\circ} 00^{\prime} 05^{\prime \prime}$ & 34.115 & 29.11 & 4236 \\
\hline S6 & N 16⒌59'59" & E $116^{\circ} 58^{\prime} 59^{\prime \prime}$ & 34.108 & 29.37 & 3990 \\
\hline S7 & N $17^{\circ} 00^{\prime} 83^{\prime \prime}$ & E $115^{\circ} 59^{\prime} 72^{\prime \prime}$ & 34.298 & 29.26 & 4013 \\
\hline S8 & $\mathrm{N} 17^{\circ} 00^{\prime} 10^{\prime \prime}$ & $\mathrm{E} 115^{\circ} 00^{\prime} 50^{\prime \prime}$ & 34.051 & 29.00 & 2490 \\
\hline S9 & N 180. $04^{\prime} 01^{\prime \prime}$ & E $115^{\circ} 01^{\prime} 47^{\prime \prime}$ & 34.483 & 28.43 & 3700 \\
\hline S10 & N 17º $82^{\prime} 97^{\prime \prime}$ & E $115^{\circ} 87^{\prime} 11^{\prime \prime}$ & 34.470 & 28.80 & 3844 \\
\hline S11 & N 1800'44" & E $117^{\circ} 00^{\prime} 81^{\prime \prime}$ & 34.187 & 29.32 & 3930 \\
\hline $\mathrm{S} 12$ & N 1800'14" & E $118^{\circ} 00^{\prime} 14^{\prime \prime}$ & 34.249 & 29.40 & 4300 \\
\hline S13 & N $18^{\circ} 59^{\prime} 85^{\prime \prime}$ & E $117^{\circ} 59^{\prime} 68^{\prime \prime}$ & 34.278 & 28.21 & 3733 \\
\hline S14 & N 1900'10" & E $117^{\circ} 00^{\prime} 13^{\prime \prime}$ & 34.461 & 27.64 & 3700 \\
\hline S15 & N 18⒌ $59^{\prime} 76^{\prime \prime}$ & E $116^{\circ} 02^{\prime} 72^{\prime \prime}$ & 34.264 & 28.00 & 3000 \\
\hline S16 & N 190'ㄷㄴ & $\mathrm{E} 115^{\circ} 01^{\prime} 53^{\prime \prime}$ & 34.301 & 27.98 & 2240 \\
\hline S17 & N 19²1'92" & E $116^{\circ} 36^{\prime} 09^{\prime \prime}$ & 34.481 & 27.89 & 2156 \\
\hline $\mathrm{S} 18$ & N $19^{\circ} 44^{\prime} 07^{\prime \prime}$ & E $116^{\circ} 12^{\prime} 10^{\prime \prime}$ & 34.443 & 27.17 & 1773 \\
\hline S19 & N $20^{\circ} 06^{\prime} 08^{\prime \prime}$ & E $115^{\circ} 48^{\prime} 01^{\prime \prime}$ & 34.464 & 26.58 & 979 \\
\hline S20 & N $20^{\circ} 21^{\prime} 01^{\prime \prime}$ & E $115^{\circ} 37^{\prime} 17^{\prime \prime}$ & 34.441 & 26.59 & 520 \\
\hline $\mathrm{S} 21$ & N 20 $33^{\prime} 03^{\prime \prime}$ & E $115^{\circ} 27^{\prime} 88^{\prime \prime}$ & 34.413 & 26.38 & 302 \\
\hline $\mathrm{S} 22$ & $\mathrm{~N} 20^{\circ} 42^{\prime} 30^{\prime \prime}$ & E $115^{\circ} 75^{\prime} 46^{\prime \prime}$ & 34.596 & 25.29 & 230 \\
\hline $\mathrm{S} 23$ & N 204ㄴㄷㄴ & E $115^{\circ} 15^{\prime} 14^{\prime \prime}$ & 34.610 & 24.83 & 195 \\
\hline
\end{tabular}




\section{ACCEPTED MANUSCRIPT}

Table 2. Distribution of DMS, DMSPd, DMSPp and chlorophyll $a$ in the surface microlayer and subsurface water of the South China Sea during May 2005.

\begin{tabular}{|c|c|c|c|c|c|c|c|c|c|c|c|c|}
\hline \multirow[t]{2}{*}{ Station no. } & \multicolumn{3}{|c|}{ DMS (nM) } & \multicolumn{3}{|c|}{ DMSPd (nM) } & \multicolumn{3}{|c|}{ DMSPp (nM) } & \multicolumn{3}{|c|}{ Chlorophyll $a\left(\mu \mathrm{g} \mathrm{L}^{-1}\right)$} \\
\hline & $\mathrm{C}_{\mathrm{S}}{ }^{\mathrm{a}}$ & $\mathrm{C}_{\mathrm{M}}{ }^{\mathrm{b}}$ & $\mathrm{EF}^{\mathrm{c}}$ & $\mathrm{C}_{\mathrm{S}}$ & $\mathrm{C}_{\mathrm{M}}$ & $\mathrm{EF}$ & $\mathrm{C}_{\mathrm{S}}$ & $\mathrm{C}_{\mathrm{M}}$ & $\mathrm{EF}$ & $\mathrm{C}_{\mathrm{S}}$ & $\mathrm{C}_{\mathrm{M}}$ & $\mathrm{EF}$ \\
\hline S1 & 1.88 & 1.59 & 0.85 & 6.31 & 7.51 & 1.19 & 8.16 & 8.88 & 1.09 & 0.074 & 0.062 & 0.84 \\
\hline S2 & 1.61 & 1.07 & 0.66 & 2.89 & 3.52 & 1.22 & 5.98 & 4.85 & 0.81 & 0.047 & 0.047 & 1.0 \\
\hline S3 & 1.00 & 1.02 & 1.02 & 2.59 & 3.05 & 1.18 & 6.41 & 6.92 & 1.08 & n.d. & 0.076 & n.d. \\
\hline S4 & 2.02 & 1.55 & 0.77 & 4.95 & 5.70 & 1.15 & 6.28 & 7.48 & 1.19 & 0.067 & 0.056 & 0.84 \\
\hline S5 & 1.70 & 1.22 & 0.72 & 4.88 & 5.40 & 1.11 & 8.45 & 7.06 & 0.84 & 0.076 & 0.060 & 0.79 \\
\hline S6 & 1.85 & 1.05 & 0.57 & 5.01 & 5.80 & 1.16 & 6.59 & 4.36 & 0.66 & 0.076 & 0.045 & 0.59 \\
\hline S7 & 2.08 & 1.21 & 0.58 & 2.42 & 5.20 & 2.15 & 5.20 & 4.52 & 0.87 & 0.081 & 0.069 & 0.85 \\
\hline S8 & 1.66 & 1.17 & 0.70 & 2.95 & 5.79 & 1.96 & 5.20 & 3. & 0.98 & 0.070 & 0.050 & 0.71 \\
\hline S9 & 1.41 & 1.32 & 0.94 & 3.20 & 6.60 & 2.06 & 3.89 & 4.50 & 1.16 & 0.065 & 0.100 & 1.5 \\
\hline S11 & 1.63 & 1.94 & 1.19 & 6.54 & 8.95 & 1.37 & 6.76 & 8.05 & 1.19 & 0.067 & 0.091 & 1.4 \\
\hline S12 & 1.66 & 1.05 & 0.63 & 2.55 & 5.13 & 2.01 & 5.67 & 7.23 & 1.28 & n.d. & 0.071 & n.d. \\
\hline S13 & 1.88 & 1.41 & 0.75 & 3.42 & 5.57 & 1.63 & 7.80 & 7.80 & 1.00 & 0.12 & 0.15 & 1.3 \\
\hline S14 & 1.70 & 1.23 & 0.72 & 2.58 & 3.94 & 1.53 & 5.92 & 7.05 & 1.19 & 0.091 & 0.086 & 0.95 \\
\hline $\mathrm{S} 15$ & 2.04 & 1.78 & 0.87 & 4.82 & 5.26 & 1.09 & 7.18 & 7.07 & 0.98 & 0.088 & 0.11 & 1.3 \\
\hline S16 & 2.05 & 1.65 & 0.80 & 2.21 & 2.97 & 1.34 & 4.52 & 5.85 & 1.29 & 0.072 & 0.072 & 1.0 \\
\hline S17 & 1.61 & 1.04 & 0.65 & 4.70 & 4.40 & 0.94 & 3.77 & 3.90 & 1.03 & 0.088 & 0.075 & 0.85 \\
\hline S18 & 1.60 & 1.01 & 0.63 & 3.47 & 2.70 & 0.78 & 5.75 & 6.27 & 1.09 & 0.098 & 0.095 & 0.97 \\
\hline S19 & 1.32 & 2 & 0.93 & 2.51 & 6.43 & 2.56 & 3.40 & 5.20 & 1.53 & 0.085 & 0.091 & 1.1 \\
\hline S20 & 1.46 & 0.81 & 0.55 & 3.23 & 3.31 & 1.02 & 5.50 & 5.59 & 1.02 & 0.086 & 0.095 & 1.1 \\
\hline $\mathrm{S} 21$ & 1.52 & 0.90 & 0.59 & 3.49 & 4.30 & 1.23 & 4.68 & 4.42 & 0.94 & 0.069 & 0.052 & 0.75 \\
\hline S22 & 2.05 & 1.42 & 0.69 & 5.74 & 5.33 & 0.93 & 8.68 & 7.55 & 0.87 & 0.086 & 0.072 & 0.84 \\
\hline S23 & 2.50 & 1.95 & 0.78 & 5.76 & 7.00 & 1.21 & 7.42 & 4.58 & 0.62 & 0.095 & 0.090 & 0.95 \\
\hline Average & $1.74 \pm 0.0$ & $.30 \pm 0$. & $75 \pm 0.11$ & $3.92 \pm 0.34$ & $.18 \pm 0.4$ & $.40 \pm 0.15$ & $6.06 \pm 0.51$ & $.10 \pm 0.57$ & $.03 \pm 0.13$ & 0.080 & 0.078 & 0.98 \\
\hline \multicolumn{13}{|c|}{${ }^{\mathrm{a}}$ The subsurface water concentration; } \\
\hline \multicolumn{13}{|c|}{${ }^{\mathrm{b}}$ The microlayer concentration; } \\
\hline \multicolumn{13}{|c|}{${ }^{\mathrm{c}}$ The ratio of $\mathrm{C}_{\mathrm{M}}$ to $\mathrm{C}_{\mathrm{S}}$; } \\
\hline
\end{tabular}




\section{ACCEPTED MANUSCRIPT}

Table 3. The calculated $S c$ and $K_{D M S}$ values and sea-to-air fluxes of DMS in the South China Sea.

\begin{tabular}{ccccc}
\hline Station no. & $\begin{array}{c}\text { Wind speed* } \\
\left(\mathrm{m} \mathrm{s}^{-1}\right)\end{array}$ & $S c$ & $\begin{array}{c}K_{D M S} \\
\left(\mathrm{~cm} \mathrm{~h}^{-1}\right)\end{array}$ & $\begin{array}{c}F_{D M S} \\
\left(\mu \mathrm{mol} \mathrm{m}^{-2} \mathrm{~d}^{-1}\right)\end{array}$ \\
\hline S1 & 6.2 & 621 & 7.84 & 2.99 \\
S2 & 4.6 & 603 & 3.44 & 0.88 \\
S3 & 1.2 & 577 & 0.21 & 0.05 \\
S4 & 2.9 & 598 & 0.49 & 0.18 \\
S5 & 0.3 & 611 & 0.05 & 0.01 \\
S6 & 4.7 & 605 & 3.72 & 0.94 \\
S7 & 6.4 & 607 & 8.50 & 2.47 \\
S8 & 1.4 & 614 & 0.23 & 0.06 \\
S9 & 9.9 & 630 & 18.0 & 5.70 \\
S11 & 2.0 & 606 & 0.34 & 0.16 \\
S12 & 2.5 & 604 & 0.42 & 0.11 \\
S13 & 3.0 & 636 & 0.49 & 0.17 \\
S14 & 6.7 & 652 & 9.01 & 2.66 \\
S15 & 8.3 & 642 & 13.5 & 5.77 \\
S16 & 7.1 & 642 & 10.2 & 4.04 \\
S17 & 5.7 & 645 & 6.32 & 1.58 \\
S18 & 5.9 & 665 & 6.76 & 1.64 \\
S19 & 7.2 & 683 & 10.1 & 2.98 \\
S20 & 8.2 & 682 & 12.8 & 2.49 \\
S21 & 8.7 & 688 & 14.1 & 3.05 \\
S22 & 7.8 & 722 & 11.4 & 3.89 \\
S23 & 6.2 & 737 & 7.18 & 3.36 \\
Average & 5.3 & 640 & 6.59 & 2.06 \\
\hline & & & & \\
\hline
\end{tabular}

*Measured at $10 \mathrm{~m}$ height 


\section{Figure Captions}

Fig. 1. Location of the sampling stations in the South China Sea.

Fig. 2. Variations in the microlayer DMS, DMSPd, DMSPp and chlorophyll $a$ concentrations with their subsurface water concentrations.

Fig. 3. Diagram of DMS and DMSPp:chlorophyll $a$ ratios in all the seawater samples.

Fig. 4. Diel variations in chlorophyll $a$, DMS and DMSP at anchor station S10. 


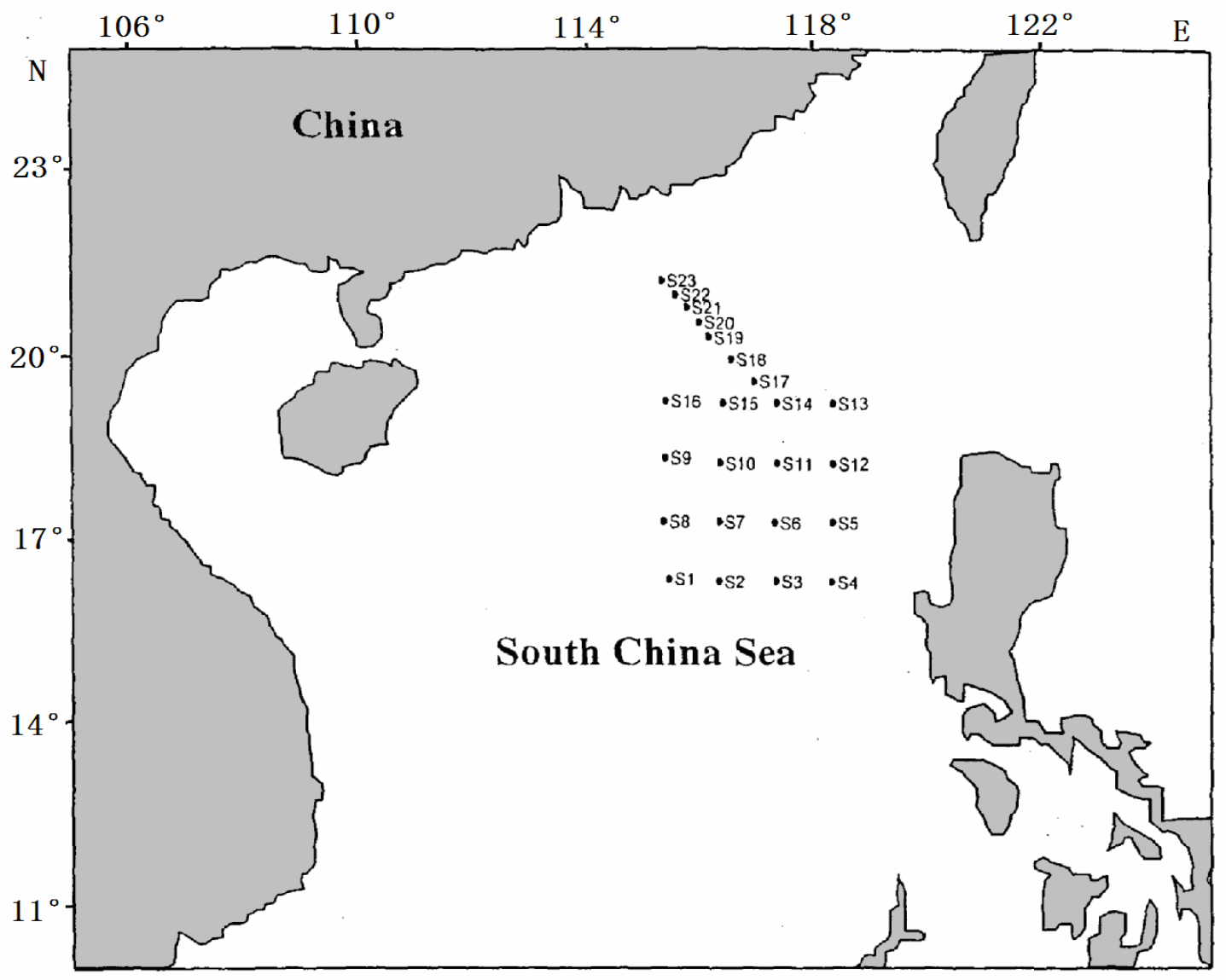

Fig. 1. Location of the sampling stations in the South China Sea. 

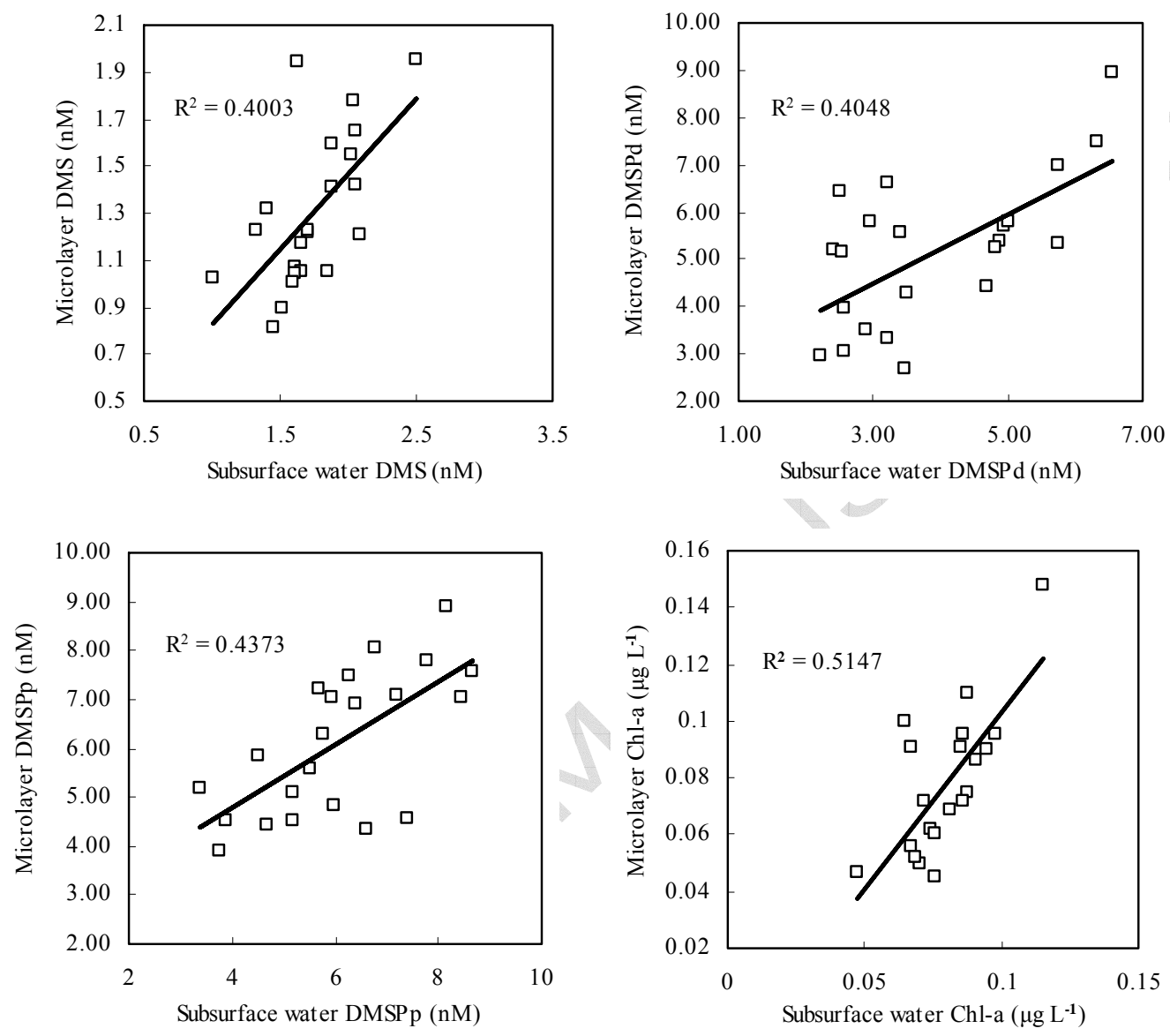

Fig. 2. Variation in the microlayer DMS, DMSPd, DMSPp and chlorophyll $a$ concentrations with their subsurface water concentrations. 


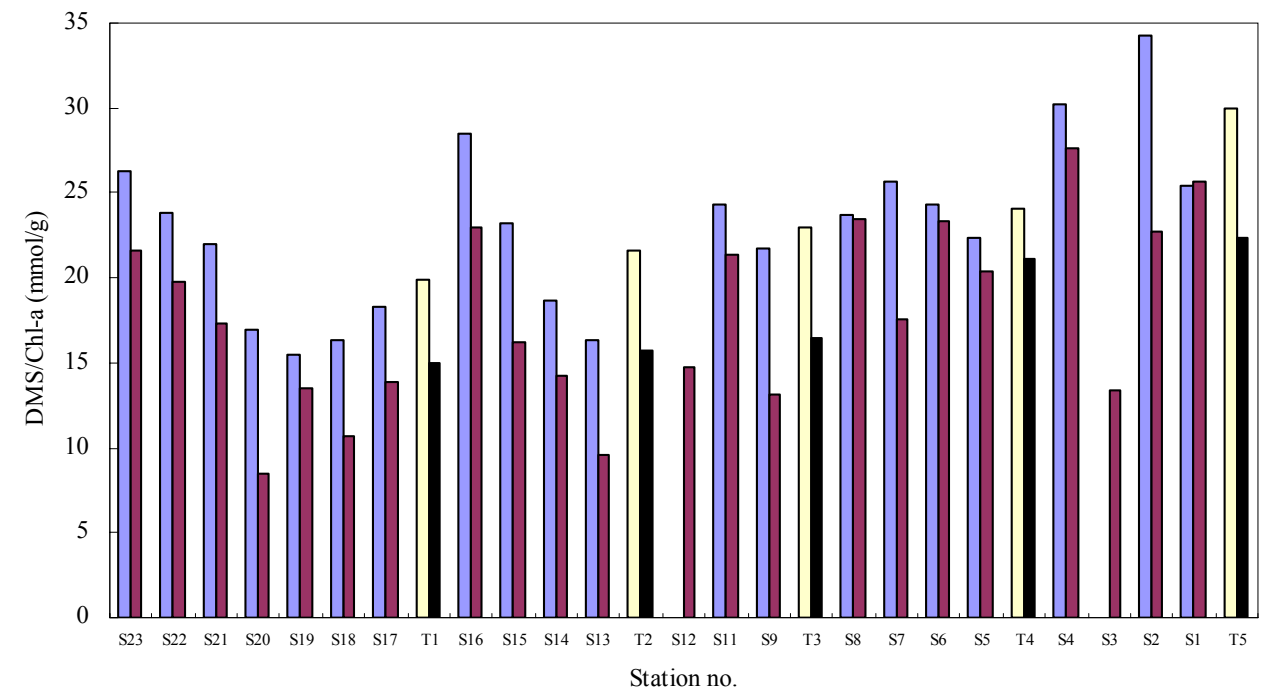

$\square$ Subsurface samples $\quad \square$ Microlayer samples $\quad \square$ Average of subsurface $\quad$ Average of microlayer

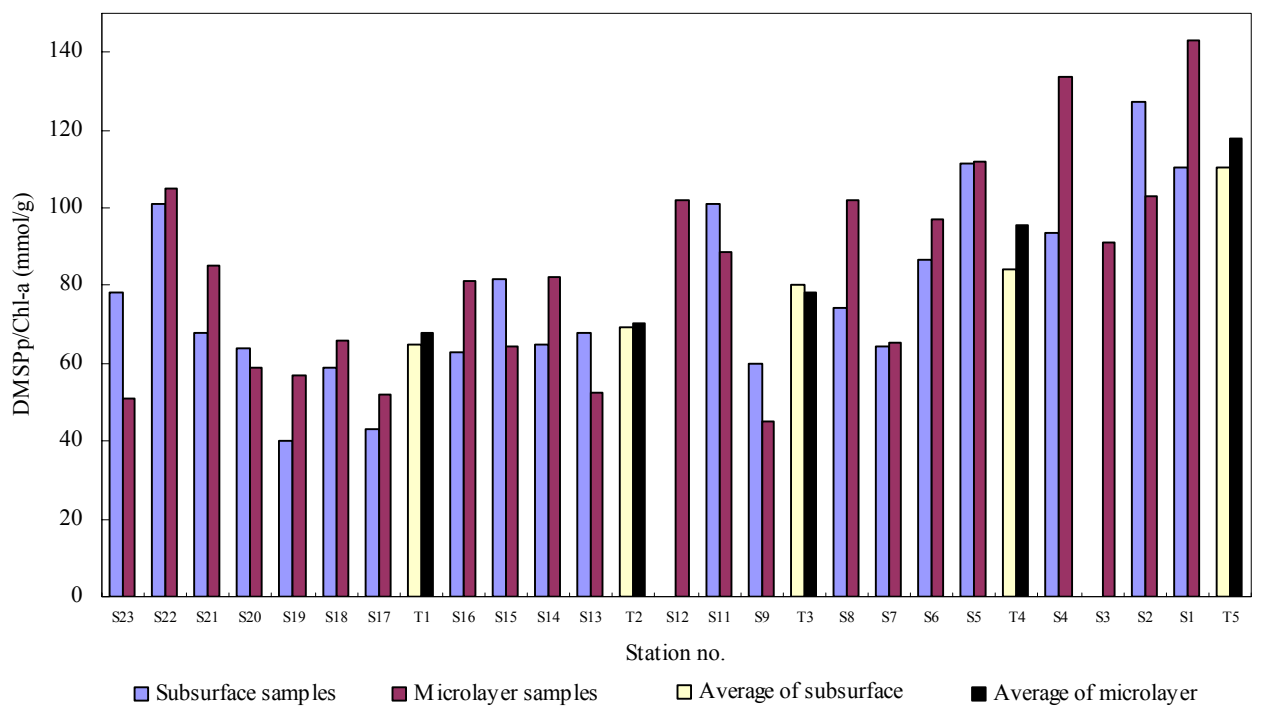

Fig. 3. Diagram of DMS and DMSPp : chlorophyll $a$ ratios in all the seawater samples. 

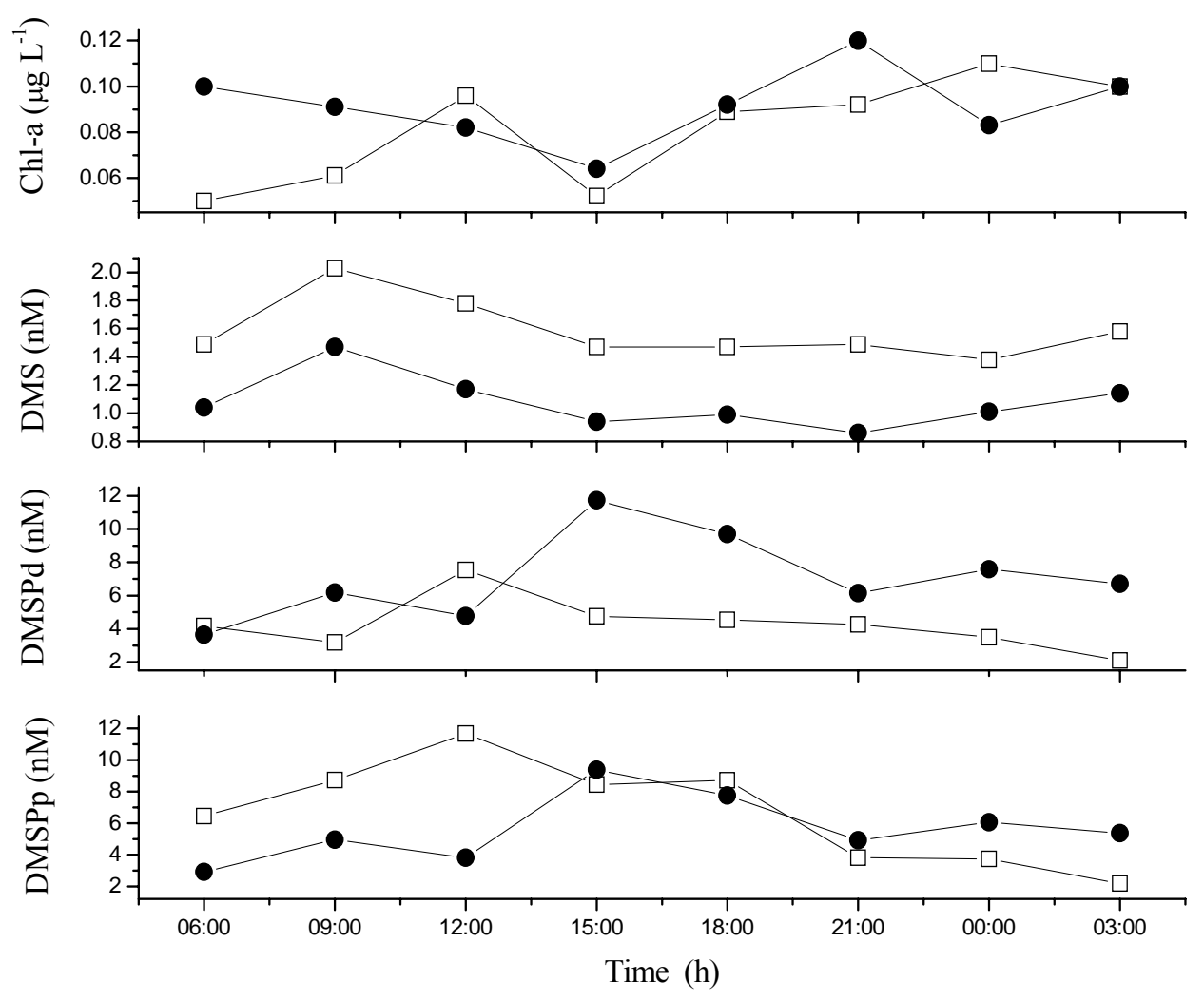

$-\square-$ Subsurface $-\bullet-$ Microlayer

Fig. 4. Diel variations in chlorophyll $a$, DMS and DMSP at anchor station S10. 